\title{
MIĘDZY UNIWERSALNOŚCIĄ A PARTYKULARNOŚCIĄ, CZYLI O POLSKICH PUBLIKACJACH PEDAGOGICZNYCH
}

Streszczenie: Prezentowany artykuł jest zbiorem uwag dotyczących uwarunkowań bibliometrycznej oceny publikacji pedagogicznych. Zawiera spostrzeżenia odnośnie do dwóch typów uwarunkowań oceny bibliometrycznej: kontekstualnych, odnoszących się do administracyjnych regulacji w uprawianiu nauki (zwłaszcza nauk humanistycznych), oraz wewnątrzpedagogicznych, opisujących specyfikę tej dyscypliny naukowej.

W szczególności w tekście wskazane zostały wątpliwości dotyczące zasadności wiązania ocen bibliometrycznych z poznawczą wartością badań prowadzonych w dziedzinie pedagogiki. Prezentowany tekst broni poznawczej wartości badań pedagogicznych oraz zawiera propozycję zwrotnego odniesienia tytułowej opozycji: uniwersalność-partykularność, czyli zastosowania jej do kryteriów, jakie stosowane są przy indeksacji pedagogicznego dorobku naukowego. Wskazuje się w nim, że zasadne są pytania dotyczące adekwatności, niemiarodajności oraz potrzeby stosowania tego typu ocen. Uzmysławia się wątpliwości związane nie $\mathrm{z}$ uniwersalnością pedagogiki, ale z uniwersalnością samego pomiaru i stosowanych w jego ramach kryteriów.

Słowa kluczowe: pomiar bibliometryczny, pedagogika, indeksacja dorobku naukowego z zakresu pedagogiki, kryteria pomiaru bibliometrycznego.

Artykuł jest zbiorem uwag dotyczących bibliometrycznej oceny pedagogicznych publikacji naukowych. Nie ma on charakteru syntetycznego, całościowo ujmującego podjęte zagadnienie, lecz jest on aspektowy i analityczny. W szczególności odnosi się do uwarunkowań w pozycjonowaniu (indeksacji) polskiego dorobku pedagogiki, prezentowanego w czasopismach oraz w naukowych publikacjach zwartych. Ponieważ artykuł pisany jest z pozycji pedagoga ogólnego, ujmuje przedmiotowe zagadnienie w optyce naukowca zainteresowanego upowszechnieniem wyników

\footnotetext{
* Dr hab. Piotr Magier, adiunkt, Katolicki Uniwersytet Lubelski Jana Pawła II w Lublinie, Katedra Pedagogiki Ogólnej Instytutu Pedagogiki; e-mail: piotr.magier@kul.lublin.pl.
} 
badań, jakie realizuje, nie zaś z punktu widzenia specjalisty z zakresu bibliotekoznawstwa. Tak materialnie, jak i formalnie określony przedmiot umiejscawia prezentowany tekst $\mathrm{w}$ grupie pedagogicznych analiz metaprzedmiotowych. Jego badawczą podstawę (źródło, materiał badawczy) stanowią polskojęzyczne teksty naukowe poświęcone problematyce oceny (ewaluacji) dorobku naukowego.

Refleksję dotyczącą podjętego problemu uznaję za ważną i aktualną, a nawet konieczną. Odnosi się ona do istotnych dla funkcjonowania każdej nauki zagadnień: poznawczej wartości prowadzonych badań, możliwości upowszechniania dorobku naukowego, specyfiki teoretycznej pedagogicznych szkół i środowisk naukowych oraz uwarunkowań akceptacji i obecności ich twórczości w szerszym: ogólnopolskim lub światowym dorobku naukowym. Prowokuje ona także do postawienia fundamentalnych dla pedagogiki pytań, dotyczących istoty humanistyki, jej miejsca w strukturze nauk oraz funkcji w cywilizacji łacińskiej.

Już na wstępie chcę zaznaczyć, że oceny bibliometrycznej tekstów pedagogicznych nie utożsamiam $z$ ich poznawczym aspektem: znaczeniem, wartością, funkcją. Choć uznaję, że zachodzić może między nimi jakiegoś (?) typu związek, sądzę, że nie jest to zależność przyczynowo-skutkowa ani proporcja. Mniemam, że nie można punktów przyznawanych poszczególnym publikacjom w prosty sposób identyfikować $\mathrm{z}$ ich wartością poznawczą.

W tekście staram się odpowiedzieć na następujące pytania: czym jest warunkowana ocena publikacji z zakresu pedagogiki?, w jakim stopniu lub zakresie dorobek pedagogiki ze swej istoty jest partykularny (lokalny), a w jakim uniwersalny?; w jakiej sytuacji znajdują się polscy pedagodzy aspirujący do upowszechnienia wyników własnych badań?

Tekst składa się ze wstępu, części zawierającej ogólne uwagi wprowadzające, części poświęconej określeniu zewnętrznych (kontekstualnych) uwarunkowań percepcji i oceny dorobku tej nauki oraz części poświęconej określeniu wewnętrznych (specyficznych dla pedagogiki) uwarunkowań odbioru, pozycjonowania i popularyzacji wiedzy pedagogicznej.

Zdaję sobie sprawę z tego, że zaprezentowane uwagi mogą być odebrane jako (nadmiernie) krytyczne, innym razem (z innej perspektywy) jako oczywiste, banalne lub subiektywne. Traktuję je jako zachętę do dyskusji, okazję do wyrażenia własnego stanowiska, nie zaś jako receptę na rozwiązanie pojawiających się przed piśmiennictwem pedagogicznym problemów. Ich dyskusyjny charakter dotyczy faktu, że są one wyrazem moich osobistych doświadczeń w uprawianiu nauki (uwarunkowane są przez to, rzecz jasna, poziomem mojego rozwoju naukowego, środowiskiem naukowym, w jakim pracuję oraz dyscypliną, którą uprawiam), są efektem podejmowanych rozmów i dyskusji, podczas których niejednokrotnie podkreślane są trudności w uzyskaniu wysokiej oceny bibliometrycznej publikacji z pedagogiki oraz są konsekwencją przyjmowanej zazwyczaj przeze mnie postawy, którą określić można jako rozumiejącą, konserwatywną oraz apologetyczną względem poznawczej i praktycznej wartości badań i publikacji pedagogicznych. 


\section{Uwagi wprowadzające}

Stanu polskiego piśmiennictwa pedagogicznego nie da się sprowadzić do prostych opisów i wyjaśnień. Jest to zjawisko wieloaspektowe i złożone. Mimo że twierdzenie to jest truizmem, warto je przytoczyć, gdyż nie zawsze jest ono brane „na poważnie”, a przynajmniej tak się wydaje. Uproszczone interpretacje kondycji nauki w Polsce wypowiadane są systematycznie przez polityków, publicystów, dziennikarzy, a niekiedy także samych naukowców. Zawierają one krytyczne konstatacje odnoszące się do stanu polskiej nauki, ocenę jej niskiego poziomu oraz proste wskazówki wyjścia z tej sytuacji, notabene najczęściej sprowadzające się do aspektów finansowania, uwarunkowań politycznych i zarządzania nauką, w tym do konieczności coraz bardziej rygorystycznej oceny (ewaluacji) dorobku naukowego (Ćwiek 2021; Nowakowska 2021; Wittenberg 2018; Mirowska-Łoskot 2017).

Tego typu podejście uznaję za redukcjonistyczne, populistyczne (względem władz zarządzających nauką) i niejednokrotnie krzywdzące dla polskich naukowców. Sądzę, że opisując podjęty w artykule problem, ujmować go należy jako złożony i bynajmniej nieoczywisty. W analizach mu poświęconych uwzględniać trzeba zarówno uwarunkowania podmiotowe (osobowe, dotyczące naukowców), jak i przedmiotowe (dotyczące nauki, typu nauk lub konkretnej dyscypliny naukowej), aktualne i temporalne (historyczne), istotowe i kontekstualne. Ponadto za cenne poznawczo uznaję spostrzeżenie, że wspomniane uwarunkowania mogą ze sobą konwergować: znosić się lub wzmacniać. Mogą funkcjonować na poziomie szczegółowych niuansów lub na poziomie ogólnych prawidłowości. Nie zawsze przydatne są detaliczne i wieloaspektowe opisy i wyjaśnienia. Bywa, że cenne poznawczo są syntezy ujmujące ogólne prawidłowości (Franczuk 2016).

Nie można także pominąć faktu, że analizy i oceny dotyczące wartości publikacji naukowych, zwłaszcza humanistycznych (pedagogicznych), są w jakiś sposób sprofilowane, zaangażowane teoretycznie lub światopoglądowo. Są one osadzone w różnych poglądach i podejściach badawczych (metodologicznych). Ich wymowa warunkowana jest uprzednimi założeniami, stawianymi celami lub interesami. Ocena dorobku naukowego nie jest zatem oczywista i sama przez się zrozumiała. Wymaga nie tyle dyrektywnego wprowadzania, ile pogłębionego, wyrażonego wprost wyjaśniania, które służy zarówno adresatom oceny (naukowcom), jak i jej pomysłodawcom (Mizerek 2018).

Porządkując wymienione wyżej uwarunkowania oceny bibliometrycznej publikacji naukowych, sprowadzam je do dwóch typów. Pierwszy typ uwarunkowań dotyczy szeroko pojętego kontekstu uprawiania nauk. Chodzi zwłaszcza o regulacje prawne, aspekty polityczne oraz o ,intelektualny klimat”, w ramach którego uprawiana jest dana dziedzina nauki.. Dla ich oznaczenia używam określenia „uwarunkowania zewnątrz pedagogiczne” lub „uwarunkowania kontekstualne”.

Drugi typ stanowią uwarunkowania dotyczące nauki, w ramach której publikacje są generowane. W prezentowanym tekście, dla ich oznaczenia w odniesieniu 
do pedagogiki, używam określenia „uwarunkowania wewnątrz pedagogiczne”. Odnoszę je zarówno do metodologicznej, jak i teoretycznej specyfiki pedagogiki, rozumianej jako odrębna, autonomiczna dyscyplina wiedzy.

\section{Uwarunkowania kontekstualne}

Na wstępie powtórzę uwagę, że bibliometryczna ocena publikacji pedagogicznych nie odzwierciedla poznawczej lub praktycznej wartości prezentowanych w nich treści, czyli że de facto nie określa ona naukowego poziomu prowadzonych w pedagogice badań. Głównym źródłem generowania ocen wyrażonych w punktach przyznawanych publikacjom pedagogicznym (ale też publikacjom z innych dyscyplin) są elementy kontekstu uprawiania nauki: przepisy prawa, zaradność autorów tekstów, zależności polityczne i ideologiczne, jakim podlega pedagogika (czy szerzej: nauka), dominujący paradygmat, w ramach którego jest ona uprawiana.

Biorąc pod uwagę czynniki zewnętrzne stwierdzić należy, że o parametryzacji dorobku pedagogicznego (podobnie jak dorobku innych nauk) decydują przede wszystkim przepisy obowiązującego prawa państwowego. Mimo że zależność ta wydaje się powszechnie akceptowana, a jej zasadność dla wielu osób jest oczywista, to jej istota, jak również (realne lub potencjalne) konsekwencje są brzemienne w skutkach. Głównie chodzi o to, że to nie naukowcy (pedagodzy) decydują o wartości własnego dorobku naukowego (przynajmniej nie wprost), lecz urzędnicy ${ }^{1}$. Oni w konsekwencji określają, co jest w nauce pożyteczne i cenne, a co za takie uchodzić nie może $e^{2}$. Oczywiście, sytuacja jest bardziej złożona. Wydaje się, że decyzje podejmowane przez organy administracyjne opierają się na konsultacjach prowadzonych wśród specjalistów z danej dziedziny (czy w ogóle na postulatach naukowców) ${ }^{3}$,

1 Równie zdecydowany sprzeciw budzi wśród niektórych naukowców próba oceny słuszności określonych tez wypowiadanych przez humanistów (historyków) przed sądami: „Nauka nie jest po to, by służyć dobremu imieniu, ani dumie narodowej. Nauka jest od obiektywnego dochodzenia prawdy, niechby bolesnej i raniącej. Skądinąd, jakże trzeba być pozbawionym wiary we własne racje, aby przeciwstawiać wieloletnim badaniom znawców tematu pozew sądowy? Sąd jako instytucja oceniająca pracę uczonych - czy naprawdę „obrońcy dobrego imienia” nie dysponują bardziej wiarygodnym narzędziem?” (Stachowiak 2021).

2 Bogusław Śliwerski wielokrotnie zwracał uwagę na polityczne uwarunkowania funkcjonowania nauki i edukacji (Śliwerski 2020).

3 Ksiądz Profesor Zygmunt Zieliński w następujący sposób opisuje konsultacje społeczne, jakim podlegała tzw. Konstytucja dla nauki lub Ustawa 2.o: „Ostatnio słyszałem, jak jeden z profesorów, chyba z UJ, powiedział, że nie było w Polsce żadnego przedsięwzięcia, które byłoby poddane tak szerokiej konsultacji społecznej, jak reforma szkolnictwa wyższego pana Gowina. Nie tylko ja zdumiałem się ta wypowiedzią. Trudno ją nawet skomentować. Ludzie na uczelniach po prostu boją się w ogóle wypowiadać w tej materii, bo w końcu nawet posada profesora „dydaktycznego" to jest kawałek chleba, ale mówić o szerokiej konsultacji społecznej i to dającej poparcie dla wyczynów pana ministra, to już jest coś więcej niż to, na co policja pozwala. To się nazywa 
niemniej nawet w tej sytuacji bezpośrednim podmiotem decyzyjnym pozostają pracownicy instytucji rządowych lub reprezentanci organów ustawodawczych.

Niestety, wspomniane niejasności nie są rzeczą trywialną, bez znaczenia dla rozwoju nauki. Wątpliwości, jakie pojawiają się w tej materii, dotyczą merytorycznych kompetencji osób podejmujących tego typu decyzje, a także odnoszą się do genezy ustalanych przez te osoby kryteriów oceny (ich obiektywności) publikacji naukowych (pedagogicznych) i dalekosiężnego wpływu na naukę. Niektórzy badacze wprost wypowiadają tezę o braku istnienia merytorycznych podstaw dla podejmowania decyzji administracyjnych określających wartości punktowe stosowane przy ocenie poszczególnych tekstów, publikacji, grantów badawczych lub czasopism naukowych. Nie znajdują oni jasnych, transparentnych uzasadnień dla wprowadzanych kryteriów (Mizerek 2018).

Niestety, wspomniane niejasności mają szerszy zakres. Odnoszą się także do systemowych zmian, jakim podlega nauka, w tym do przeprowadzonej ostatnio w Polsce reformy systemu nauki i szkolnictwa wyższego. Traktowane są jako działania szkodliwe, ingerujące w niezależność funkcjonowania badawczego i dydaktycznego uniwersytetów, a przez to mające charakter destrukcyjny (Zieliński 2019). W konsekwencji sięgają one problemu autonomii tej podstawowej instytucji naukowej oraz niezależności badań naukowych i dydaktyki uniwersyteckiej (Bocheński 1993).

Problematyka autonomii uniwersytetu oraz ingerencji różnych podmiotów $\mathrm{w}$ uprawianie nauki nie jest oczywiście nowa. Pojawiła się już u zarania istnienia tej instytucji naukowej, a w miarę jej rozwoju narastała, wzbudzając stałe, żywe dyskusje. W ich trakcie wytworzyły się dwa modele relacji między uniwersytetem a władzą państwową i kościelną: klasyczny (średniowieczny i humanistyczny) podkreślający konieczność autonomii uniwersytetu oraz oświeceniowy (związany z reformacją i kontrreformacją) - uwypuklający potrzebę podporządkowania uniwersytetów władzy świeckiej (Bocheński 1993). Niezależnie od przyjętego modelu przyznanie uniwersytetowi pewnego (określonego kompromisem między interesem państwa lub Kościoła a interesem uniwersytetu) stopnia autonomii, a także uszanowanie niezależności badań i procesu kształcenia jest uznawane za potrzebne, a nawet konieczne. Sądzi się, że tylko wówczas uniwersytet służyć może zarówno dobru społeczności, wśród której istnieje, jak i realizować własne cele (Bocheński 1993).

$\mathrm{W}$ przypadku parametryzacji dorobku naukowego, ingerencja instytucji zewnętrznych w działanie uniwersytetów, a dokładniej w funkcjonowanie instytutów i dyscyplin naukowych jest znaczna. Dotyczy ona zarówno gwarancji finansowych i administracyjnych ich istnienia, jak i możliwości rozwoju naukowego

pytać tych, którzy zawsze odpowiadają zgodnie z życzeniem pytającego. Jaka konsultacja, taka reforma” (Zieliński 2019, s. 14). 
pracowników uniwersyteckich. Sięga ona zatem podstaw autonomii uniwersytetu: możliwości kontynuacji badań, a przez to ciągłości określonej szkoły badawczej ${ }^{4}$.

Niepokój związany z ograniczeniem autonomii nauki ze względu na wpływ podmiotów zewnętrznych pojawia się już w sytuacji oddziaływania instytucji państwowych. Spowodowany jest on zależnością tych instytucji od partii politycznych i lansowanych przez nie poglądów i ideologii. Jest on jednak większy, gdy naukę podporządkowuje się nie tylko instytucjom państwowym lub religijnym, czy podmiotom o mimo wszystko ustalonej powadze i wiarygodności, lecz także korporacjom prywatnym. Oceny parametryczne jednostek naukowych realizowane przez państwo, formułowane są bowiem na podstawie miejsca publikacji tekstów naukowych, a konkretnie tego, czy dane czasopismo lub wydawnictwo obecne jest w określonych bazach, nierzadko będących własnością prywatną.

Wydaje się, że właśnie z tych względów we współczesnym podejściu do oceny, lecz też nierzadko do uprawiania nauki, nie dominuje ujęcie mądrościowe i humanistyczne, lecz podejście komercyjne. Oczekiwanym rezultatem badań naukowych nie jest już teoria, lecz efekt poznawczy podlegający komercjalizacji, sprzedaży, przynoszący korzyści finansowe, wiedza typu know how ${ }^{5}$. Reguły pracy naukowej podlegają regułom handlu, a uniwersytet staje się korporacją. W efekcie pozytywnie cenieni są ci pracownicy, którzy generują zyski, nie zaś ci, którzy tworzą wiedzę systemową, teoretyczną̧. Przyjmowane współcześnie rozwiązania, dotyczące pożądanych sposobów uprawiania nauki, są sprzeczne w swej istocie $\mathrm{z}$ jej modelem klasycznym, humanistycznym. Model ten rozwijał się bowiem jako model teoretyczny, niepraktyczny. Takie ujęcie gwarantowało poznawczy postęp w nauce i sytuowało uniwersytet $\mathrm{w}$ gronie instytucji kulturotwórczych?

4 Nie jest to problem trywialny, chodzi mianowicie o możliwość wykluczania z dyskursu uniwersyteckiego (naukowego) poglądów, z różnych powodów niewygodnych. Na problem ten zwracają uwagę m.in.: Dariusz Stępkowski (2010), w aspekcie pedagogiki chrześcijańskiej, czy Piotr Zychowicz (2016), w odniesieniu do drażliwych społecznie kwestii historycznych.

5 Co ciekawe, określeniem wiedzy współcześnie zajmują się nie tyle instytucje naukowe, co handlowe i polityczne, np. Międzynarodowa Izba Handlowa, Unia Europejska, Bank Światowy (Żardecka-Nowak 2012).

6 „W szkolnictwie wyższym «projakościowa» zmiana oznacza odejście od klasycznej formuły uniwersytetu rozumianego jako świątynia wiedzy i przekształcenie go w ponad narodową, biurokratyczną korporację. Praca w nim oraz zarządzanie mają być dokładną kalką procedur wypracowanych w korporacjach. Trzeba w nim zaadoptować korporacyjne, podporządkowane koncepcji nowego publicznego zarządzania [...], procedury zarządzania i zapewniania jakości, zadbać o «komercjalizację» wyników badań, wymusić konkurencyjność itp." (Mizerek 2018, s. 83).

7 „Tak więc historia uczy, że powinniśmy dać wolność czystej nauce, «spekulatywny», teoretycznym badaniom. Bo właśnie najczystsza, pozornie całkiem niepraktyczna teoria ma często rozstrzygające znaczenie dla praktyki. [...] argument [przeciwko tej tezie - dopisek autora artykułu] zakłada przesłankę, że kto płaci rozkazuje. I ta przesłanka jest w zasadzie prawdziwa, ale z jednym ważkim wyjątkiem: nie ma mianowicie zastosowania do dziedzin duchowych. [...] 
Biznesowe podejście do nauki likwiduje jeszcze jeden, klasycznie wypracowany jej element - oparcie kształcenia nowych naukowców na modelu relacji mistrz-uczeń. Nauka nie jest już miejscem dochodzenia do rozumienia istoty określonej rzeczywistości, lecz miejscem konkurencji. Nie ma w nim miejsca na „dojrzewanie” poznawcze adeptów nauki, lecz na gotowe rozwiązania, zaradność i spryt. W ocenie dorobku pracowników nauki przestaje mieć znaczenie ich wiedza i warsztat metodologiczny: wybór wartościowego poznawczo problemu i jego poprawne metodologicznie rozwiązanie. Znaczenia ma natomiast miejsce wydania publikacji (artykułu), nawet jeśli wkład pracy poszczególnych autorów wyrażony jest w formie kilku akapitów tekstu (Zieliński 2019; Mizerek 2018).

Inne aspekty komercyjnego uprawiania nauki dotyczą aspektów moralnych (Franczuk 2016). Zaplanowana i realizowana systemowo zasada konkurencji odnosi się zarówno do poziomu uniwersyteckiego (model uniwersytetów wiodących), jak i do poziomu pracy poszczególnych naukowców (system grantów). Na każdym poziomie oparta jest ona o oceny punktowe, prowadzące do eliminacji podmiotów słabszych ${ }^{8}$. Co więcej, już w tej chwili, a więc w zasadzie na początku obowiązywania sytemu punktowego, będącego w sprzeczności z klasycznym pojmowaniem uniwersytetu jako wspólnoty, badacze zjawiska wskazują na zagrożenie etosu moralnego pracy naukowej. Zwraca się uwagę, że pogoń za punktami legitymizuje zachowania zorientowane na efekt osiągany każdym koszem i każdym sposobem. Nic zatem dziwnego, że miejsce ekskluzywnego etosu moralnego pracy naukowej zajmuje deontologiczny system szczegółowych regulacji prawnych, ewaluacji i kontroli (Andrzejuk 2014).

Równie trudnym do wyjaśnienia i uzasadnienia wydaje się problem genezy kryteriów stosowanych przy ocenie dorobku naukowego. Już elementarna wiedza z zakresu metodologii (naukoznawstwa) nakazuje zachowanie ostrożności w tym względzie. Określenie nauki jest na tyle skomplikowane (Bronk 2006; Walczak 2006), że proste odpowiedzi na pytanie o jej istotę uznać można za wyraz ignorancji. Procedury i kryteria ewaluacji dorobku naukowego, w tym oceny wartości tekstów

Trzecią [obok sztuki i religii - dopisek autora artykułu] podobną dziedziną duchową jest nauka, a więc i uniwersytet. Co prawda, mamy tu do czynienia z paradoksem, z prawdziwym wyjątkiem $\mathrm{w}$ naszym świecie. Ale ten paradoks ma podstawę w istocie ducha, w istocie cywilizacji. Tylko barbarzyńca, który ducha nie rozumie, tylko ten kto wszystko sprowadza do sfery zmysłowej, to jest zwierzęcej, może uważać wspomnianą przesłankę za obowiązującą bez wyjątku. Człowiek cywilizowany podporządkowuje siły fizyczne duchowi. Po tym się go poznaje, nie tylko gdy chodzi o sztukę i religię, ale także odnośnie do nauki” (Bocheński 1993, s. 66-67).

8 „Upowszechnia się wiarę, że droga do «projakościowej» zmiany prowadzi przez konkurencję. Akademicy muszą uczestniczyć w «wyścigu» o możliwie najwyższą kategorię naukową swojej jednostki, zabiegać o wysoki indeks cytowań oraz wierzyć w to, że system punktowania publikacji jest rzeczywiście w pełni trafnym i rzetelnym wskaźnikiem ich rzeczywistej wartości” (Mizerek 2018, s. 81). 
naukowych, wydają się tę ignorancję afirmować, a przynajmniej są skonstruowane niezależnie, a nawet wbrew wspomnianej wyżej ostrożności.

Naiwne jest także przekonanie, jakoby kryteria te nie podlegały jakimkolwiek wpływom teoretycznym oraz pozateoretycznym, i w tym sensie były obiektywne lub neutralne'. Ślepa wiara $\mathrm{w}$ jeden, praktykowany przez decyzyjne grono naukowców paradygmat uprawiania nauki w prosty sposób prowadzi do dyskredytacji innych paradygmatów, co jest wyrazem obskurantyzmu metateoretycznego (metodologicznego) ${ }^{10}$ i przynosi realne szkody nauce i kulturze (Żardecka-Nowak 2012). Mit o światopoglądowej neutralności nauki jest tym bardziej groźny, że budzi on ślepe do niej zaufanie, uniwersalizację i usypia krytycyzm. Brak świadomości tego typu zależności daje możliwość tym łatwiejszej manipulacji, realizowanej „W imię nauki” (McGrath 2008; Pedersen 1997).

Wydaje się, że mimo różnorakich zależności administracyjnych, jakim podlega nauka, podstawowym elementem kontekstualnie warunkującym ocenę publikacji pedagogicznych (humanistycznych) w aspekcie teoretycznym jest dominacja matematycznego przyrodoznawstwa i naturalizmu metodologicznego. Mimo że osiągnięcia poznawcze i nadbudowane na nich efekty praktyczne (technika) nauk przyrodniczych są niepodważalne, niepokojące i nie do zaakceptowania dla humanistów jest też maksymalistyczne zorientowanie naturalistycznego modelu uprawiania nauki. Choć takie podejście na terenie humanistyki jest możliwe, świadczy o tym np. psychologia lub socjologia, wzorem są tu nauki przyrodnicze (Szacki 2007; Stachowski 2010), okazuje się, że wiele zagadnień typowo humanistycznych

9 „Czasy współczesne pokazują niestety, iż ewaluację można wykorzystywać również w procesie wprowadzania reform, o których trudno powiedzieć, że niosą one za sobą zmianę na lepsze. Opłakane skutki dla edukacji przynosi współcześnie dominacja neoliberalnego dyskursu zmiany. Tworzą go, wyrażając to w języku interdyskursywnej analizy, trzy tematy [...] - złoty standard (gold standard), praktyka oparta na dowodach naukowych (evidence based-practice) oraz badania eksperymentalne znane w literaturze jako model RCT (randomized controlled trial)" (Mizerek 2018, s. 79).

10 Alister Mc Grath - teolog protestancki, biofizyk, profesor Uniwersytetu w Oxfordzie w następujący sposób opisuje własne doświadczenia dotyczące „odkrycia” poznawczej wartości humanistyki: „Nauki przyrodnicze kochałem od czasu, gdy tylko pamiętam, że cokolwiek kochałem. [...] Nauki przyrodnicze były nie tylko fascynujące intelektualnie i zachwycające estetycznie, ale ponadto podawały w wątpliwość przekonania religijne, a zatem otwierały drogę do lepszego świata. [...] kiedy poznałem już cały księgozbiór biologiczny w szkolnej bibliotece naukowej natrafiłem na dział, którego dotąd nie zauważyłem. Nazywał się «Historia i Filozofia Nauki» i był pokryty grubą warstwą kurzu. Nie miałem zbyt wiele czasu na tego typu rozważania, zresztą uważałem je za dyletancką krytykę oczywistości i pewników nauk przyrodniczych, uprawianą przez ludzi, dla których wiedza stanowiła zagrożenie, a których działalność Dawkins nazwał później «zagłuszaniem prawdy». Filozofia, podobnie jak teologia, wydawała się tylko zbędną spekulacją o sprawach, które można wyjaśnić za pomocą paru rzetelnych eksperymentów. [...] Rzeczywistość okazała się bardziej złożona niż przypuszczałem. Otworzyły mi się oczy i zobaczyłem, że nie ma już powrotu do uproszczonego obrazu nauki, jaki dotąd znałem" (McGrath 2008, s. 8-10). 
wyłączonych wtedy zostaje poza zakres nauki. Przyjęte standardy naukowe prowadzą do zawężenia zakresu badań nauk humanistycznych, a niekiedy wręcz do ich zaniku.

Maksymalizm naturalistyczny, podważający naukowość teologii, filozofii i nauk humanistycznych, zarysowany został już w filozofii pozytywnej Augusta Comtea, prowokując szeroką dyskusję i obronę naukowego statusu humanistyki (Wilhelm Dilthey, Wilhelm Windelband, Heinrich Rickert, Georg Simmel, Max Weber). Sformułowane na przełomie XIX i XX wieku uwagi pozostają aktualne. Także współcześnie dyskusja na temat naukowości humanistyki zogniskowana jest na problemach wskazanych przez klasyków metodologii nauk humanistycznych. Chodzi o takie metodologiczne problemy, jak: odrzucenie dominacji metody badawczej na przedmiotem badań, idiograficzność i normatywność humanistyki, jej rozumiejący i historyczny charakter, typologiczność stosowanych na jej terenie podziałów (Kamiński 1992). Także dyskusja dotyczące pedagogiki jako dyscypliny humanistycznej właśnie ich dotyczy (Magier 2016).

\section{Uwarunkowania wewnątrz pedagogiczne}

Redukcjonizmem i hipokryzją byłoby utożsamianie przyczyn trudności w uzyskaniu wysokiej oceny parametrycznej, z jakimi (niekiedy) borykają się autorzy tekstów pedagogicznych, jedynie z przyczynami kontekstualnymi, niezależnymi od samych pedagogów. Oczywiście, także w odniesieniu do pedagogiki oraz do sposobu funkcjonowania naukowców uprawiających tę dyscyplinę wiedzy wykazać można pewne elementy wpływające na ocenę bibliometryczną. Chodzi przede wszystkim o: dzieje pedagogiki, określenie naukowej (metodologicznej) tożsamości tej dyscypliny, akceptację (lub jej brak) różnorodnych stanowisk teoretycznych w niej istniejących oraz o nawyki badawcze i publikacyjne, jakie utrwaliły się wśród pedagogów.

Rozpocznę od uwag historycznych, które w myśl paradygmatu humanistycznego umożliwiają rozumienie aktualnego stanu opisywanych zjawisk. Nie chodzi przy tym o usprawiedliwienie obecnie istniejących niedociągnięć, lecz o lepsze pojmowanie stanu faktycznego. Otóż, mimo że powstanie pedagogiki, jako autonomicznej wiedzy uniwersyteckiej, wiązane jest z osiągnięciami administracyjnymi i teoretycznymi Jana Fryderyka Herbarta, to proces kształtowania się tożsamości teoretycznej i metodologicznej tej nauki był rozłożony w czasie i nadal nie wydaje się zakończony (Salamucha 2010). Zwłaszcza pedagogika w Polsce doświadczała różnorakich okoliczności ograniczających możliwości jej autonomicznego rozwoju. Jej rozkwit w okresie dwudziestolecia międzywojennego zahamowany został w okresie PRL-u ${ }^{11}$. Dopiero przełom polityczny i społeczny lat 9o. stworzył warunki dla ad-

11 „Odnoszę wrażenie, że badacze, którzy pierwsze naukowe stopnie zdobywali w czasach komunizmu nie potrafią się odnaleźć w wolnorynkowej rzeczywistości. Nie zauważyli, że 
ministracyjnej i teoretyczno-ideologicznej autonomii pedagogiki (Stępkowski 2010). Przy czym nie bez znaczenia dla sytuacji, w jakiej znajduje się obecnie pedagogika, były procesy i zjawiska, jakim dyscyplina ta wówczas podlegała. Wielu autorów podkreśla, że po odrzuceniu paradygmatu pozytywistyczno-marksistowskiego, obowiązującego w Polsce przez około 50 lat, pedagogika znalazła się w sytuacji teoretycznej i ideologicznej pustki. Dla znacznej grupy pedagogów była ona równoznaczna z kryzysem pedagogiki ujętej en bloc, czasem poszukiwania inspiracji i możliwych do akceptacji paradygmatów (Urbaniak-Zając, Kot 2013).

Metodologiczna i teoretyczna stabilizacja w polskiej pedagogice wyraźnie pojawiła się na początku obecnego wieku. Jednak już pod koniec jego drugiej dekady uniwersytecki system uprawiania nauki w Polsce został poddany kolejnym, systematycznie kontynuowanym zabiegom reorganizacji (reformom). W efekcie po krótkim okresie stabilizacji pedagogika wraz z całym systemem nauki w Polsce weszła w okres nowych systemowych zmian ${ }^{12}$.

Mimo że okres po 1945 roku w Polsce trudno uznać za korzystny dla rozwoju nauki, wydaje się, że nie wszystkie dyscypliny humanistyczne (społeczne), a tym bardziej przyrodnicze, doświadczyły tego typu traumy, a przynajmniej nie w takim samym co pedagogika stopniu. Warunki, w jakich się one rozwijały, nie były identyczne, lub nawet porównywalne do okoliczności funkcjonowania i rozwoju pedagogiki pierwszoplanowo i systemowo poddanej ideologizacji. Ich specyfika przedmiotowa i metodologiczna, oparte na naturalizmie, przynajmniej częściowo chroniły je przez wpływem ideologii marksistowskiej (Stachowski 2010).

Współcześnie pedagogika jest uprawiana na różne sposoby, w ramach różnych paradygmatów i na różnym poziomie zaawansowanie teoretycznego i metodologicznego. Jeśli założymy, że oceny bibliometryczne pozostają w związku z treścią publikacji, możemy przyjąć, że dorobek pedagogiczny, pomijając kwestie historyczne, bywa różnie oceniany właśnie ze względy na paradygmat badań, $\mathrm{w}$ ramach którego są one prowadzone oraz na jego zaplecze teoretyczne. Dlatego istotne, $\mathrm{z}$ punktu widzenia podjętej $\mathrm{w}$ artykule problematyki, jest zwrócenie uwagi na rozbieżności w naturalistycznym i antynaturalistycznym modelu uprawiania pedagogiki. Wydaje się, że cenione są publikacje stanowiące rezultat badań inspirowanych naturalizmem metodologicznym (a więc publikacje będące sprawozdaniem $\mathrm{z}$ badań empirycznych), w przeciwieństwie do badań inspirowanych ujęciami

funkcjonowanie systemów finansowania się zmieniło - to znaczy są świadomi tych zmian, ale działają zgodnie ze swoimi przyzwyczajeniami. Jakby wszyscy dostawali swoje, po równo. Zapominają, że ubieganie się o fundusze, to dziś rodzaj przetargu, w którym wygrywają badacze mający czym się pochwalić oraz przedstawiający realistyczne wizje projektu $\mathrm{z}$ adekwatnym kosztorysem. Tymczasem wielu polskich naukowców nie dba o tak proste sprawy, jak terminy sprawozdawcze, rzetelny wizerunek" (Franczuk 2016).

12 Proces wprowadzania systemu ewaluacji systemu edukacji, w tym ewaluacji akademickiej, opisuje Henryk Mizerek w artykule Ewaluacja edukacyjna w Polsce. Trajektorie, perspektywy i dylematy rozwoju (Mizerek 2016). 
antynaturalistycznymi oraz (w tym) prowadzonych z poziomu teorii i metateorii (Mizerek 2018).

Ekspansja i dominacja naturalizmu metodologicznego w nauce współczesnej nie tworzy korzystnej sytuacji dla dociekań pedagogicznych uprawianych w modelu (paradygmacie) humanistycznym. Mimo że pedagogika może być w pewnych aspektach uprawiana na wzór nauk przyrodniczych, nie sposób uprawiać pedagogiki w tym modelu en bloc. Chodzi zwłaszcza o jej poziom normatywny, teoretyczny, które nie są akceptowane (a nierzadko nawet rozpoznawane, identyfikowane) w modelu naturalistycznym (Magier 2016). W konsekwencji, mimo że badania empiryczne prowadzone na terenie pedagogiki znajdują uznanie i zainteresowanie w pedagogice światowej (Mizerek 2018), trudniej jest upowszechniać analizy teoretyczne. Nie chodzi przy tym o treść czy poziom tych analiz, lecz o to, że prezentują one refleksje nieempiryczne, oceniające i postulatywne, które nierzadko są uznawane za nienaukowe i poznawczo mało istotne.

Kuriozalne w tym kontekście jest negatywne postrzeganie i brak akceptacji dla teorii i metateorii w pedagogice. Oba zakresy badawcze są bowiem istotne, a nawet kluczowe dla każdej nauki, w tym pedagogiki. Z definicji wiadomo, że wiedza naukowa to wiedza ogólna. Nie istnieje nauka bez teorii. Natomiast namysł metateoretyczny stanowi gwarant spójności metodologicznej każdej nauki. Co więcej, to właśnie teoria nadaje badaniom empirycznym znaczenia poznawczego. Ich wartość poznawcza oceniana jest z pozycji znaczenia dla wygenerowaniu teorii określonego zjawiska ${ }^{13}$. Ich realizacja wyłącznie dla celów wąskiego opisu (ilustracji) zastanych zależności (tj. niezależnie od teorii) jest być może ciekawa z punkty widzenia praktycznego lub aplikacyjnego, jednak poznawczo jałowa (Dziaczkowska 2014).

Podobnie rzecz się ma, jeśli chodzi o aspekt ocen i norm w pedagogice. Naturalistyczny model uprawiania nauki prowadzi nie tylko do odrzucenia normatywnego i postulatywnego zakresu (poziomu) pedagogiki, lecz co ważniejsze - do zakwestionowania metodologicznej spójności pedagogiki. Sytuacja ta wyraźnie jest widoczna w anglosaskiej i frankońskiej tradycji uprawiania pedagogiki (różnych od tradycji niemieckiej), w których nie istnieje ona jako jedna, spójna metodologicznie dyscyplina wiedzy. Wiedza pedagogiczna stanowi kompleks nauk o edukacji, luźno związanych ze sobą metodologicznie (Magier 2016).

Niezrozumiała jest także niechęć do publikacji pedagogicznych z zamierzenia nastawionych na opis i wyjaśnienie zjawisk oraz procesów występujących lokalnie. Humanistyczne badania, istotne dla określonego kraju lub regionu, nie zawsze znajdują szersze zainteresowanie w czasopismach wysoko punktowanych. Chodzi

13 Wskazana sytuacja dotyczy krytyki naukotwórczej funkcji indukcji oraz wartości poznawczej zdań protokolarnych. Po początkowej fascynacji nimi, już w ramach neopozytywizmu (antyindukcjonizm, falsyfikacjonizm), podważono ich autonomiczną wartość poznawczą (Bronk 2006). 
chociażby o takie zagadnienia, jak etymologiczne i pojęciowe analizy językowe ${ }^{14}$ (analizy języka pedagogiki, który w znacznej mierze jest językiem narodowym), badanie dziejów pedagogiki oraz lokalnego dorobku teoretycznego lub praktycznego. Pedagodzy, prowadzący badania, które potencjalnie mogą być wysoko ocenione i publikowane w czasopismach międzynarodowych, z konieczności skazani są na rezygnację z tekstów istotnych dla lokalnej teorii i praktyki edukacyjnej, adresowanych do najbliższych im kulturowo i terytorialnie naukowców i praktyków oraz z pisania w języku narodowym. Źródła publikowane w języku ojczystym, z których korzystać mogą studenci i praktycy już w chwili obecnej, są znacznie okrojone, a teksty publikowane w językach obcych nie posiadają szerokiej możliwość kształtowania ojczystej kultury lokalnej (Bartmiński 2013).

Globalna, nieuwzględniająca lokalnych uwarunkowań indeksacja dorobku naukowego, prowadzić może do przynajmniej jeszcze jednego zagrożenia pedagogiki, a mianowicie do marginalizacji naukowego znaczenia niektórych szkół i środowisk naukowych. Jak wiadomo, pedagogika, z racji swojego normatywnego charakteru, odwołuje się nie tylko do dorobku naukowego, lecz także korzysta z treści światopoglądowych i ideologicznych. Na podstawie tego typu danych określa chociażby normy i cele, jak również założenia bazowe, tworząc różnorodne nurty i kierunki pedagogiczne. Nie chcąc demonizować tej zależności, za naiwne uznać jednak można myślenie, $w$ ramach którego różnym ośrodkom naukowym czy zespołom redakcyjnym przypisuje się zupełną neutralność lub brak zaangażowania światopoglądowego oraz politycznego. Autorzy tekstów naukowych (humanistycznych) muszą po prostu liczyć się z poprawnością polityczną czy światopoglądową, nawet jeśli wymóg ten nie jest wyrażany wprost ${ }^{15}$.

\section{Zakończenie}

Ocena bibliometryczna dorobku publikacyjnego z zakresu pedagogiki pozostaje konsekwencją sytuacji, w jakiej znajduje się współczesna nauka, a zwłaszcza humanistyka. Nauka nie jest zjawiskiem jednorodnym i stałym, lecz polimorficznym i zmiennym. Podobnie jak inne wytwory kulturowe oraz społeczne podlega nieustannym przekształceniom. Historia pokazuje, że długotrwała dominacja jednego modelu nauki nie jest możliwa, a trwanie przy starych, skostniałych formach organizacji nie wpływa korzystnie na naukę i na jej rozwój. Wypracowane w pewnej

14 Innym problemem jest określenie, jak bardzo zależności przedmiotowe, stanowiące przedmiot badań, można precyzyjnie wyrazić w języku obcym (angielskim), nawet przy pomocy specjalistycznych tłumaczeń (Zieliński 2019).

15 Na zależność między badaniami humanistycznymi a wymogami prawności politycznej zwracają uwagę m.in. Piotr Zychowicz (Zychowicz 2016), Stanisław Kowalczyk (2000), Barbara Kiereś (2015). 
epoce rozwiązania administracyjne, teoretyczne i metodologiczne dotyczące nauki nie są w stanie obronić się przed zmianami kulturowymi i wpływem nowych idei.

Sytuacja, w jakiej znalazła się współczesna nauka, jest niewątpliwie wyjątkowa, przełomowa. Na naszych oczach dokonuje się nie tylko akcydentalna, administracyjna reorganizacja nauki, lecz także pojawiają się zmiany sięgające jej istoty. W przypadku humanistyki, w tym pedagogiki, wydaje się, że spowodowane są one procesami wewnątrznaukowymi oraz wpływem, jaki współczesna cywilizacja wywiera na człowieka. Parafrazując tezę Francisa Fukuyamy (Fukuyama 2004), dotyczącą ingerencji współczesnej cywilizacji w naturę człowieka, zasadnym staje się pytanie, czy w związku z tym mamy do czynienia z końcem humanistyki i końcem pedagogiki, przynajmniej uprawianej w taki sposób, jaki znamy dotychczas? Czy na współczesnym uniwersytecie, który ma "charakter korporacyjny” jest "agresywną firmą wcielającą etos wielkiego biznesu i napędzany ideą wydajności” (Żardecka-Nowak 2012, s. 191), jest miejsce na pedagogikę uprawianą jako dyscyplina humanistyczna?

\title{
BETWEEN UNIVERSALITY AND PARTICULARITY - OR ABOUT POLISH PEDAGOGICAL PUBLICATIONS
}

\begin{abstract}
The presented article is a compendium of critiques concerning the conditions for the bibliometric evaluation of pedagogical publications. It contains reflections on two types of determinants of bibliometric evaluation: contextual, referring to the administrative regulations that govern doing science (especially the humanities); and intra-pedagogical regulations that describe the specificity of this academic discipline.

In particular, the text expresses doubts concerning the validity of associating bibliometric evaluations with the cognitive value of studies conducted in the field of pedagogy. In defending the cognitive value of pedagogical studies, the presented text contains a proposal for the reversible reference of the opposites comprising the title universality - particularity, i.e. its application to the criteria used in the indexation of pedagogical academic output. It indicates that there are justified questions concerning the adequacy and unreliability of, and need for, applying this type of evaluation. It highlights the doubts relating not to the universality of pedagogy but to the universality of the very measurement, and the criteria used within its framework.
\end{abstract}

Keywords: bibliometric measurement, pedagogy, indexing academic output in the field of pedagogy, criteria for bibliometric measurement. 


\section{Bibliografia}

Andrzejuk A. (2014). Etyka pracownika nauki. „Studia Tomistyczne”, nr 3, s. 205-215.

Bartmiński J. (2013). Głos w dyskusji o polskiej humanistyce. „PAUza Akademicka”, nr 233, s. 2.

Bocheński J.M. (1993). Autonomia uniwersytetu. W: Bocheński J.M. Sens życia i inne eseje. Kraków: Wydawnictwo PHILED, s. 6o-71.

Bronk A. (2006). Metoda naukowa. „Nauka”, nr 1, s. 47-64.

Ćwiek J. (2021). Ćwiek: Punktoza na uczelniach ma się dobrze. „Rzeczpospolita”. Dostępny na: https://www.rp.pl/Komentarze/210219787-Cwiek-Punktoza-nauczelniach-ma-sie-dobrze.html (dostęp 13.02.2021).

Dziaczkowska L. (2014). Akademickie problemy z metodologia pedagogiki. „Roczniki Pedagogiczne", nr 6 (42), z. 1, s. 33-51.

Fukuyama F. (2004). Koniec człowieka. Konsekwencje rewolucji biotechnologicznej. Kraków: Wydawnictwo Znak.

Franczuk M. (2016). 6 czynników, które utrzymuja polskie uczelnie w ogonie Europy. „Inn: Poland”. Dostępny na: https://innpoland.pl/blogi/ martynafranczuk/126115,6-czynnikow-ktore-utrzymuja-polskie-uczelnie-w-ogonie-europy (dostęp 13.02.2021).

Kamiński S. (1992). Nauka i metoda. Pojęcie nauki i klasyfikacja nauk. Pietrzyk B. (tłum.). Lublin: Towarzystwo Naukowe KUL.

Kiereś B. (2015). U podstaw pedagogiki personalistycznej. Filozoficzny kontekst sporu o wychowanie. Lublin: Wydawnictwo KUL; Polskie Towarzystwo Tomasza z Akwinu.

Kowalczyk S. (200o). Wolność natura i prawem człowieka - indywidualny i społeczny wymiar wolności. Sandomierz: Wydawnictwo Diecezjalne w Sandomierzu.

McGrath A. (2008). Bóg Dawkinsa. Geny, memy i sens życia. Gilewicz J. (tłum.). Kraków: Wydawnictwo Uniwersytetu Jagiellońskiego.

Magier P. (2016). Wprowadzenie. W: Marczewski M. (red.). Pedagogika rodziny. Podejście systemowe. Tom 1: Familiologia. Gdańsk: Wyższa Szkoła SpołecznoEkonomiczna w Gdańsku, s. 35-40.

Mirowska-Łoskot U. (2017). Dlaczego polski uniwersytet nigdy nie będzie jak Harvard. I czy to na pewno źle? „Dziennik Gazeta Prawna”. Dostępny na: https://serwisy. gazetaprawna.pl/edukacja/artykuly/1085351,debata-nowoczesne-zarzadzanie-uczelniami-i-ksztalcenie-studentow.html (dostęp 13.02.2021).

Mizerek H. (2016). Ewaluacja edukacyjna w Polsce. Trajektorie, perspektywy i dylematy rozwoju. „Zarządzanie Publiczne”, nr 1 (33), s. 1-16. Dostępny na: https:// www.researchgate.net/publication/304998851_Ewaluacja_edukacyjna_w_ Polsce_Trajektorie_perspektywy_i_dylematy_rozwoju (dostęp 11.02.2021).

Mizerek H. (2018). Ewaluacja edukacyjna w obliczu pytań o teraźniejszość i zmianę. Szkic do portretu szans niewykorzystanych Sketching lost opportunities: Evaluation confronting questions about the present and change. Dostępny na: https://www. 
researchgate.net/publication/328654377_Ewaluacja_edukacyjna_w_obliczu_ pytan_o_terazniejszosc_i_zmiane_Szkic_do_portretu_szans_niewykorzystanych_Sketching_lost_opportunities_Evaluation_confronting_questions_ about_the_present_and_change (dostęp 11.02.2021).

Nowakowska K. (2021). Czarnek wywraca polską naukę. Nowi faworyci? Teologia, KUL i uczelnia ojca Rydzyka. „Dziennik Gazeta Prawna”. Dostępny na: https:// serwisy.gazetaprawna.pl/edukacja/artykuly/8094229,nowy-wykaz-czasopism-czarnek-teologia.html (dostęp 13.02.2021).

Pedersen O. (1997). Konflikt czy symbioza? Z dziejów nauki między nauka a teologią. Skoczny W. (tłum.). Tarnów: Wydawnictwo Diecezji Tarnowskiej Biblos.

Salamucha A. (2010). O niektórych słabościach metodologicznych pedagogiki. W: Metodologia: tradycja i perspektywy. Walczak M. (red.). Lublin: Wydawnictwo KUL, s. 146.

Stachowiak P. (2021). Nauka przed sadem. Prof. Barbara Engelking pozwana. Dostępny na: https://wiez.pl/2021/01/29/nauka-przed-sadem-prof-barbara-engelking-pozwana (dostęp 7.02.2021).

Stachowski R. (2010). Historia współczesnej myśli psychologicznej. Od Wundta do czasów najnowszych. Warszawa: Wydawnictwo Naukowe Scholar.

Stępkowski D. (2010). Pedagogika ogólna i religia. (Re)konstrukcja zapomnianego watku na podstawie teorii Jahanna F. Herbarta i Friedricha D.E. Schleiermachera. Warszawa: Towarzystwo Naukowe Franciszka Salezego.

Szacki J. (2007). Historia myśli socjologicznej. Wydanie nowe. Warszawa: Wydawnictwo Naukowe PWN.

Śliwerski B. (2020). Crisis of democracy and education reforms in Poland after 30 years of political transformation. „Resocjalizacja Polska”, nr 19, s. 175-189. Dostępny na: https://www.researchgate.net/publication/347465981_Crisis_of_democracy_and_education_reforms_in_Poland_after_30_years_of_political_ transformation (dostęp 14.02.2021).

Urbaniak-Zając D., Kos E. (2013). Badania jakościowe w pedagogice. Warszawa: Wydawnictwo Naukowe PWN.

Walczak M. (2006). Racjonalność nauki. Problemy, koncepcje, argumenty. Lublin: Towarzystwo Naukowe KUL.

Wittenberg A. (2018). Akademicka fikcja. Polskie uczelnie udaja, że ucza. „Forsal”. Dostępny na: https://forsal.pl/artykuly/1287459,polskie-uczelnie-coraz-slabsze-system-oceny-jakosci-ksztalcenia-nie-dziala.html (dostęp 13.02.2021).

Zieliński Z. (2019). Kaganek oświaty, czy kopcacy ogarek. Rzecz o reformach oświaty i nauki. Toruń: Wydawnictwo Adam Marszałek.

Zychowicz P. (2016). Żydzi. Opowieści niepoprawne politycznie. Poznań: Dom Wydawniczy Rebis.

Żardecka-Nowak M. (2012). Uniwersytet bez idei - dyktat racjonalności instrumentalnej we współczesnym szkolnictwie wyższym. Rzeszów: Wydawnictwo Uniwersytetu Rzeszowskiego, s. 169-206. 